\title{
THE INFLUENCE OF CAT-262 C/T POLYMORPHISM ON CATALASE ACTIVITY IN PATIENTS WITH ISCHEMIC STROKE
}

\author{
Jelena Bašići ${ }^{1}$ Vuk Milošević ${ }^{2}$,Milena Despotović ${ }^{1}$, Tatjana Jevtović-Stoimenov ${ }^{1}$, \\ Tatjana Cvetković ${ }^{1}$, Milica Živanović ${ }^{1}$, Miroslava Živković2,3, Dušica Pavlović ${ }^{1}$
}

\begin{abstract}
Although there is a disturbance of oxidative stress markers in acute ischemic stroke (AIS), genetic contribution of $-262 \mathrm{C} / \mathrm{T}$ polymorphism of catalase (CAT) gene on plasma CAT activity in this disease is not yet established.

The aim of this study was to investigate the distribution of CAT-262C/T polymorphism in AIS patients compared to controls, as well as to evaluate whether this polymorphism can influence plasma CAT activity.

A total of 34 patients with AIS and 32 healthy volunteers were screened for the CAT$262 \mathrm{C} / \mathrm{T}$ gene polymorphism using the polymerase chain reaction-restriction fragment length polymorphism method (PCR-RFLP). Plasma CAT activity was determined using spectrophotometric method according to Goth.

Although the patients with the diagnosis of AIS had a higher frequency of polymorphic $-262 T$ allele in comparison to the group of healthy subjects, the difference was not statistically significant $(p=0.117)$. CAT activity was significantly lower in the patients $(12.95 \pm 2.86 \mathrm{kU} / \mathrm{L})$ compared to the controls $(25.58 \pm 13.50 \mathrm{kU} / \mathrm{L}, \mathrm{p}<0.001)$. The patients carriers of the $-262 T$ allele, showed significant decrease of plasma CAT activity $(11.93 \pm 2.82 \mathrm{kU} / \mathrm{L})$ compared to the patients with genotype $-262 \mathrm{CC}(13.99 \pm 2.59 \mathrm{kU} / \mathrm{L}, \mathrm{p}=0.039)$.

This is the first study examining the CAT-262C/T polymorphism and its influence on plasma CAT activity in AIS. Bearing in mind that the presence of $-262 \mathrm{~T}$ allele in AIS patients significantly decreased plasma catalase activity compared to CC genotype carriers, further studies should be focused on the testing of the potential protective role of the -262CC genotype in ischemic stroke.
\end{abstract}

Acta Medica Medianae 2018;57(4):110-116.

Key words: acute ischemic stroke, catalase, CAT-262C/T polymorphism

\footnotetext{
${ }^{1}$ University of Niš, Faculty of Medicine, Department of Biochemistry, Serbia

${ }^{2}$ Clinic of Neurology, Clinical Centre Niš, Niš, Serbia

${ }^{3}$ University of Niš, Faculty of Medicine, Niš, Serbia
}

Contact: Jelena Bašić

University of Niš, Faculty of Medicine

Bulevar dr Zorana Djindjića 81, 18000 Niš, Serbia

E-mail: jelena.basic@medfak.ni.ac.rs

\section{Introduction}

Acute ischemic stroke (AIS) is an episode of neurological dysfunction, caused by focal cerebral, spinal or retinal infarction (1). Stroke is the third most common cause of death, after cardiovascular disease and cancer, and is the leading cause of disability in the developed countries worldwide. Two-thirds of stroke patients develop some form of cognitive im- pairment, and every fifth patient meets the criteria for dementia (2).

A number of studies are focused on identifying complex molecular mechanisms underlying cerebral ischemia. The main cause of the reduced perfusion and ischemic brain damage is thrombosis and/or embolism. Impaired local cerebral blood flow leads to reduced oxygen and glucose delivery, which results in the disturbance of cell homeostasis and the subsequent oxidative, nitrosative stress and inflammation. Numerous studies clearly demonstrate the association between the oxidative stress and the development of neuronal cell death in brain ischemia $(3,4)$. It is believed that there are several crucial factors for the generation of reactive oxygen species (ROS), as well as reactive nitrogen species (RNS) in the ischemic area of the brain. Among them, the most prominent ones are the impaired mitochondrial function, the activation of neuronal nitric oxide synthase (nNOS) and the activation of neutrophils (5). The last process leads to the activation of NADPH oxidase. The reaction catalysed by this enzyme primarily generates superoxide anion radical which, through dismutation (a reaction catalyzed by superoxide dismu- 
tase - SOD) produces hydrogen peroxide $\left(\mathrm{H}_{2} \mathrm{O}_{2}\right)$. The interaction of superoxide anion radical and $\mathrm{H}_{2} \mathrm{O}_{2}$ leads to the formation of the most potent $\mathrm{OH}^{\bullet}$ radical, which causes cell damage and neuronal death (6).

To prevent damage, the cells contain antioxidant enzymes (SOD, catalase and glutathione peroxidase) which neutralize superoxide anions, hydrogen peroxide and lipid peroxide. Catalase (EC 1.11.1.6) (CAT), is an oxidoreductase, a tetramer of four identical subunits, each containing a polypeptide chain of 527 amino acids and a heme molecule. CAT is one of the most active and most widespread enzymes (liver, kidneys), localized in either peroxisomes or the cytosol (red blood cells - RBC). It catalyzes the decomposition reaction of $\mathrm{H}_{2} \mathrm{O}_{2}$ to water and molecular oxygen (7). Although numerous studies point to the increased production of ROS in AIS, the results of antioxidant enzymes activities in this disease are contradictory (8-10).

The CAT gene is located on chromosome $11 \mathrm{p} 13$, it has 13 exons and 410 genetic variations identified so far (11). A large number of these variations results in disturbed CAT gene expression and the change of its activity in RBC and plasma (7). Genetic variation CAT-262C/T (rs1001179) is located in the promoter region of the CAT gene. Although the results of different studies showed the correlation of this polymorphism with the risk of developing diabetes mellitus, breast cancer, hepatocellular cancer, ulcerative colitis (12-16), its functional significance in the ischemic stroke has not yet been established.

\section{Aims}

The aim of this study was to investigate the distribution of CAT-262C/T (rs1001179) genetic variation in the catalase gene in AIS patients, compared to healthy subjects, and to examine the impact of this polymorphism on patient's plasma CAT activity.

\section{Material and methods}

The study was conducted on 34 patients with ischemic stroke at the acute phase of the disease, diagnosed and treated at the Clinic of Neurology, Clinical Center Niš. Among them, there were 20 women and 14 men, average age of $62.34 \pm 2.41$. The control group consisted of 32 healthy subjects, whose gender and age corresponded to those of the affected patients. The research was conducted at the Laboratory for Functional Genomics and Proteomics, Medical Faculty, University of Niš. The present study was approved by the Ethical Committee of the Medical Faculty University of Niš, Serbia (No 12-98082/1).

Blood samples were taken within 7 days after ischemic attack. From all the blood samples (with EDTA as anticoagulant), we separated $200 \mu \mathrm{L}$ of blood, which was used for DNA isolation. The blood samples were then centrifuged at $3500 \mathrm{rpm}$ for 10 minutes at $+4^{\circ} \mathrm{C}$, after which the plasma was separated and frozen at $-80^{\circ} \mathrm{C}$.
The isolation of DNA was performed using a commercial kit for DNA isolation (Thermo Scientific GeneJET Whole Blood Genomic DNA Purification Mini Kit, Thermo Fisher Scientific). We examined the polymorphism CAT-262 C/T, using the polymerase chain reaction-restriction fragment length polymorphism method (PCR-RFLP) (17).

The fragment of 185 base pairs (bp) was amplified using a forward (5'-AGA GCC CGC TCG CCC CGG ACC G-3') and a reverse primer (5'-TAA CTG GAG AGA CAT AAG AGC T-3'). The PCR reaction mixture in a volume of $25 \mu \mathrm{L}$ contained: $12.5 \mu \mathrm{L}$ of KAPA 2G Fast HS Ready-Mix PCR kit solution (KAPA Biosystems, Germany), $0.5 \mu \mathrm{L}$ of primer $(10 \mathrm{pmol} /$ $\mu \mathrm{L})$ (Fermentas $\mathrm{GmbH}$, St. Leon-Rot, Germany) and $20 \mathrm{ng}$ of DNA. The PCR conditions were: the initial denaturation at $95^{\circ} \mathrm{C}$ for 2 minutes, followed by 35 cycles of denaturation at $95^{\circ} \mathrm{C}$ for 15 seconds, annealing at $63^{\circ} \mathrm{C}$ for 15 seconds, elongation at $72^{\circ} \mathrm{C}$ for 15 seconds, and termination at $72^{\circ} \mathrm{C}$ for 30 seconds. The amplified PCR products were visualized under UV light after agarose gel (2\%) electrophoresis.

PCR products were cut into smaller fragments by SmaI restriction enzyme (Fermentas $\mathrm{GmbH}$, St. Leon-Rot, Germany) at $37^{\circ} \mathrm{C}$ overnight and analyzed by a vertical polyacrylamide gel $(8 \%)$ electrophoresis.

Homozygous for the $\mathrm{C}$ allele (wild type) was detected as two fragments of 155 and 30bp (genotype $\mathrm{CC}$ ), while the polymorphic homozygous (TT) was shown as one fragment (185 bp). Heterozygous (CT) was confirmed by the presence of three fragments on the gel (185, 155 and $30 \mathrm{bp})$.

The plasma CAT activity was determined by Goth's spectrophotometric method (18), based on the ability of CAT to decompose the substrate $\left(\mathrm{H}_{2} \mathrm{O}_{2}\right)$, whereby the enzymatic reaction was stopped by the addition of ammonium molybdate, and the resulting yellow complex of $\mathrm{H}_{2} \mathrm{O}^{2}$ and molybdate was measured at $405 \mathrm{~nm}$ against the reagent blank. The enzyme activity was expressed in $\mathrm{kU} / \mathrm{L}$.

The frequency of alleles and genotypes in the patients and controls was analyzed and compared using $\chi^{2}$ test or Fisher exact test, but we also determined the possible deviation from the expected values of Hardy-Weinberg equilibrium tests for the patients and the control group. CAT activity in plasma was expressed as mean \pm standard deviation. The statistically significant differences in values between the patients and the control groups, as well as between the different genotypes within patients, were determined by Student's t-test for two independent samples. $P<0.05$ value was considered statistically significant. The statistical analysis was conducted using the SPSS software package version 20.0 (SPSS Inc., Chicago, IL, USA).

\section{Results}

The frequency of genotypes of the CAT$262 C / T$ polymorphism does not deviate from the 
normal distribution of Hardy-Weinberg equilibrium in patients and control groups ( $p>0.05)$.

The results shown in Table 1 indicate that the CC genotype was present in 16 (47\%) patients, while Tा genotype was present in $4(11.8 \%)$ patients. Fourteen $(41.2 \%)$ patients were heterozygous. The distribution of genotypes of the CAT-262C/T polymorphism in patients with AIS did not show a statistically significant difference compared to the control group ( $\left.\chi^{2}=2.371, p=0.306\right)$. Although the patients with the diagnosis of AIS had a higher frequency of $262 T$ allele in comparison to the group of the healthy subjects, the difference was not statistically significant $\left(\chi^{2}=2.453, \mathrm{p}=0.117\right.$; Table 2$)$.

The plasma CAT activity in the patients with AIS (12.95 $\pm 2.86 \mathrm{kU} / \mathrm{L})$ was significantly lower than in the healthy subjects $(25.58 \pm 13.50 \mathrm{kU} / \mathrm{L}, \mathrm{p}<$ 0.001; Graph 1).

The patients, carriers of the polymorphic 262T allele (CT and TT genotype), had a significantly lower CAT activity in the plasma (11.93 $\pm 2.82 \mathrm{kU} / \mathrm{L})$ compared to the CC genotype carriers (13.99 \pm 2.59 $\mathrm{kU} / \mathrm{L}, \mathrm{p}=0.039$; Graph 2).

Table 1. Genotype frequencies of the CAT-262C/T polymorphism in AIS patients and controls

\begin{tabular}{|c|c|c|c|}
\hline Genotype & $\begin{array}{c}\text { AIS } \\
\mathrm{n}=34\end{array}$ & $\begin{array}{c}\text { Controls } \\
n=32\end{array}$ & $\begin{array}{l}\mathrm{P} \text { value } \\
\left(\chi^{2} \text { test }\right)\end{array}$ \\
\hline $\mathrm{CC}$ & $16(47.0 \%)$ & $21(65.6 \%)$ & \\
\hline CT & $14(41.2 \%)$ & $9(28.1 \%)$ & 0.306 \\
\hline Tा & $4(11.8 \%)$ & $2(6.3 \%)$ & \\
\hline
\end{tabular}

Table 2. Allele frequencies of the CAT-262C/T polymorphism in AIS patients and controls

\begin{tabular}{|cccc||}
\hline Allele & $\begin{array}{c}\text { AIS } \\
2 \mathrm{n}=68\end{array}$ & $\begin{array}{c}\text { Controls } \\
2 \mathrm{n}=64\end{array}$ & $\begin{array}{c}\text { P value } \\
\left(\chi^{2} \text { test }\right)\end{array}$ \\
\hline \hline $\mathrm{C}$ & $46(67.6 \%)$ & $51(79.7 \%)$ & 0.117 \\
$\mathrm{~T}$ & $22(32.4 \%)$ & $13(20.3 \%)$ & \\
\hline
\end{tabular}

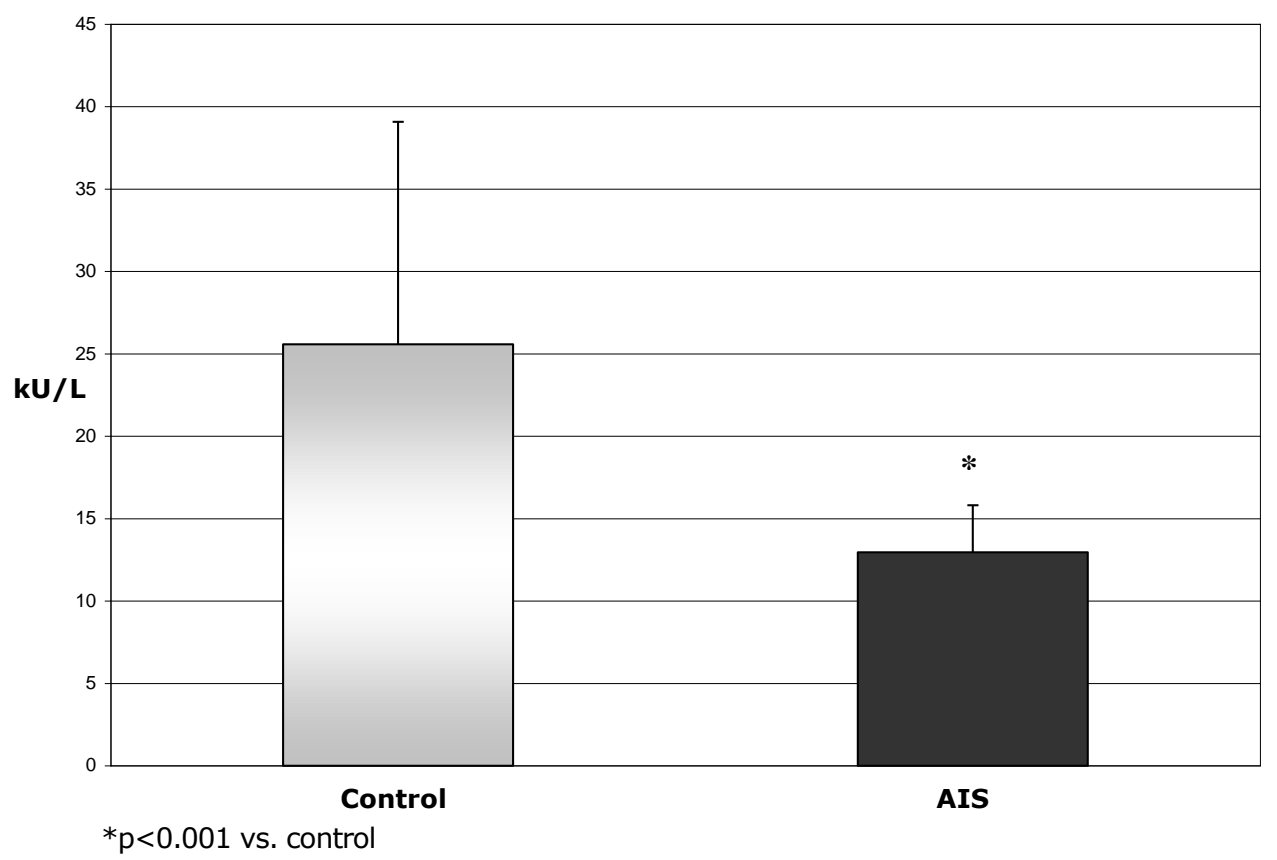

Graph 1. Plasma CAT activity in AIS patients and controls 


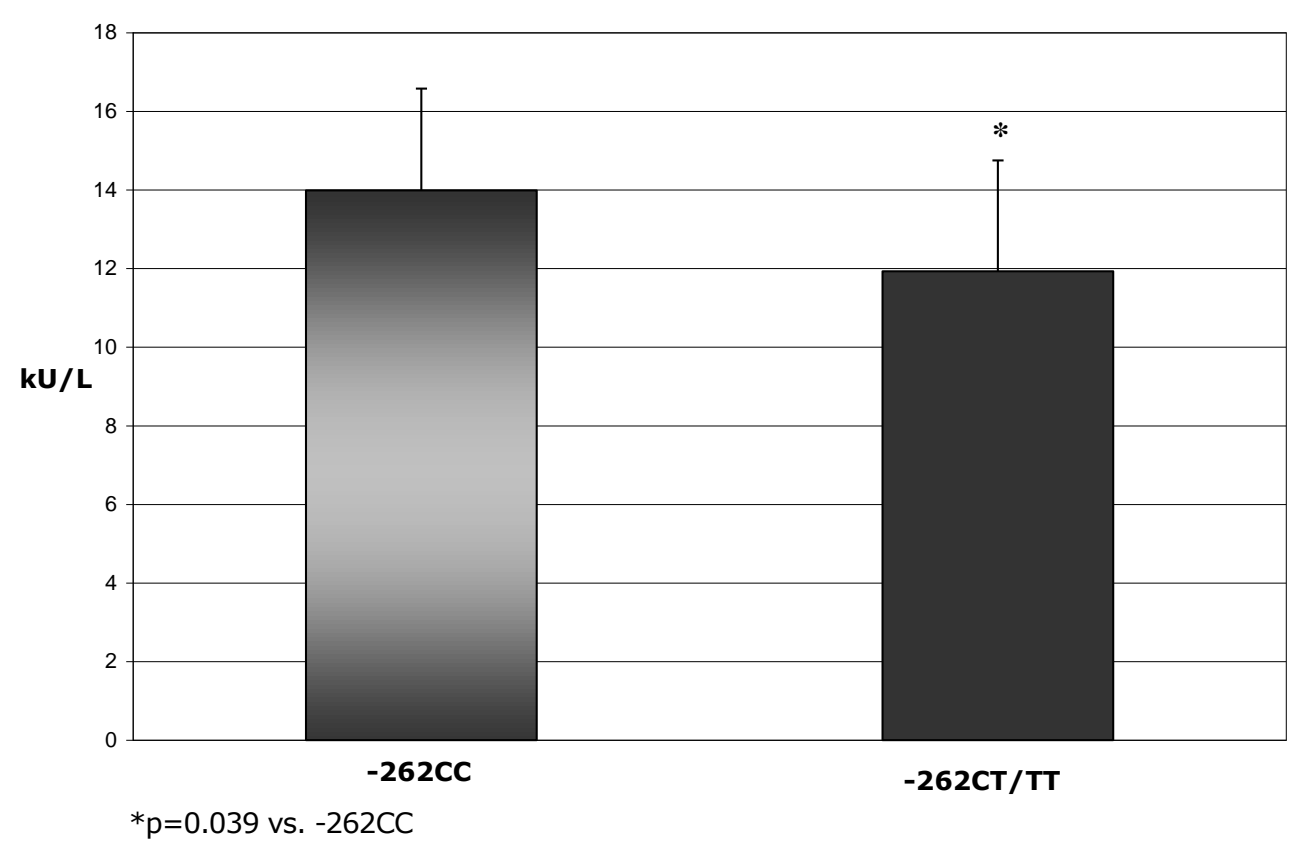

Graph 2. Plasma CAT activity in AIS patients with $-262 \mathrm{CC}$ and $-262 \mathrm{CT} / \mathrm{TT}$ genotypes of the CAT-262C/T polymorphism

\section{Discussion}

Although the CAT-262C/T polymorphism is one of the most analyzed CAT gene polymorphisms, there are no published data in regards to the role of this polymorphism in AIS. The results of this study showed no statistically significant differences in the distribution of genotypes of this polymorphism in AIS patients compared to the control group. Although the frequency of polymorphic $T$ allele was higher in the patients than in healthy subjects, the difference was not statistically significant.

The plasma CAT activity in patients with AIS in this study showed a statistically significant decrease compared to the control group.

Although it is known that oxidative stress is one of the important pathophysiological mechanisms in ischemic stroke and that it is followed by an increased concentration of lipid peroxidation products (malondialdehyde) $(9,10,19,20)$, the results of different studies regarding the antioxidative enzymes activities in this disease are contradictory.

While one group of authors (10) found an increased CAT activity in RBC, 24h, 7 days and 3 months after the ischemic stroke attack, Sheikh et al. (21) did not find a significant difference in serum CAT activity in patients with AIS compared to that of the healthy subjects.

The results of this study are in agreement with the data gathered by the three groups of authors that found a significantly lower CAT activity in the RBC of patients, $24 \mathrm{~h}, 3,5$ and 7 days after the diagnosis of ischemic stroke, when compared to the control groups $(9,22,23)$.

It is assumed that in stroke patients oxidative stress occurs not only because of the increased pro- duction of ROS, but also due to the impaired antioxidant defense system. CAT as an antioxidative enzyme is directly involved in the process of $\mathrm{H}_{2} \mathrm{O}_{2}$ elimination, which might lead to the conclusion that its high activity in plasma and RBC can have a protective effect on the neuronal damage caused by oxidative stress in stroke (24). Bearing in mind the role of oxidative stress in this disease, it is possible that the decline in CAT activity in our study was the result of the excessive accumulation of ROS generated in the brain and oxidative modification of the enzyme. On the other hand, the study results of Min et al. (25) showed that there was a reduced expression of CAT gene during ROS exposure caused by the hypermethylation of CpG region in the enzyme gene promoter, and Lehane et al. (26) indicated the correlation between the ischemic attacks and protein synthesis inhibition, it is possible that the decrease in the CAT activity in this study was the result of the reduced expression of this enzyme's gene in the conditions of oxidative stress.

So far there are no data on the functional significance of CAT-262C/T polymorphism and its possible impact on the CAT activity in AIS. The results of this study showed that patients, carriers of the polymorphic -262T allele (CT and TT genotype), have a significantly lower CAT activity in the plasma in relation to the carriers of the CC genotype.

Polymorphism at position -262 in the promoter region of CAT gene, wherein there is a substitution of cytosine by thymine, is one of the most widely analyzed polymorphism of the CAT gene. It has been shown that the polymorphism of this gene may affect its transcriptional activity by modulating the binding site for transcription factors, resulting in changes in the enzyme activity in RBC and plasma. 
While Forsberg et al. (18) found a higher CAT activity in the RBC of 29 healthy donors, carriers of the polymorphic $T$ allele, than in the CC genotype carriers, Ahn et al. (27) and Bastaki et al. (28), while conducting a study on a large number of healthy subjects (266 and 231, respectively), showed a lower CAT activity in the RBC of the polymorphic homo and heterozygous than in the CC genotype carriers.

The reduced CAT activity in this study's patients with AIS, carriers of the polymorphic -262T allele, can support the study results which indicate a low enzyme activity in the CT and TT genotypes of this polymorphism. It is possible that the decrease in the plasma CAT activity in patients with AIS can be the result of not only the oxidative modification of CAT, but also of the presence of CAT-262C/T polymorphism. A research on a large number of patients is certainly necessary in order to investigate a possible association of this polymorphism with the risk of stroke, its effect on CAT activity, and the mutual influence with the variations in other genes associated with this disease. Furthermore, future research should focus on testing the potential protective effect of CAT-262GG genotype in ischemic stroke, as well as the role of this polymorphism in the possible selection of patients for antioxidant therapy.

\section{Conclusion}

This is the first study examining the CAT-262 $\mathrm{C} / \mathrm{T}$ polymorphism and its influence on plasma CAT activity in ischemic stroke patients. Although patients diagnosed with AIS had a higher frequency of 262T allele compared to a group of healthy subjects, this difference did not reach significance. The plasma CAT activity in AIS patients was significantly lower as compared to the control group. The presence of polymorphic CAT-262T allele in patients with ischemic stroke significantly decreased the plasma CAT activity compared to the CC genotype carriers.

\section{Acknowledgments}

The financial support to this work by the Ministry of Education and Science of the Republic of Serbia (Project III41018) is gratefully acknowledged.

\section{References}

1. Sacco RL, Kasner SE, Broderick JP, Caplan LR, Connors JJ, Culebras A, et al. AHA/ASA Expert Consensus Document An updated definition of stroke for the 21st century a statement for healthcare professionals from the American Heart Association/American Stroke Association. Stroke 2013; 44:2064-89.

[CrossRef] [PubMed]

2. Suwanwela N, Koroshetz WJ. Acute ischemic stroke: overview of recent therapeutic developments. Annu Rev Med 2007; 58:89-106. [CrossRef] [PubMed]

3. Tsai NW, Chang YT, Huang CR, Lin YJ, Lin WC, Cheng $\mathrm{BC}$, et al. Association between oxidative stress and outcome in different subtypes of acute ischemic stroke. Biomed Res Int 2014:256879. [CrossRef]

4. Chen SD, Yang DI, Lin TK, Shaw FZ, Liou CW, Chuang YC. Roles of oxidative stress, apoptosis, PGC-1a and mitochondrial biogenesis in cerebral ischemia. Int J Mol Sci 2011; 12:7199-215. [CrossRef] [PubMed]

5. Guzik TJ, Korbut R, Adamek-Guzik T. Nitric oxide and superoxide in inflammation and immune regulation. J Physiol Pharmacol 2003; 54:469-87. [PubMed]

6. Warner DS, Sheng H, Batinic-Haberle I. Oxidants, Antioxidants and the Ischemic Brain. J Exp Biol 2004; 207(18):3221-31. [CrossRef] [PubMed]

7. Kodydková J, Vávrová L, Kocík M, Žák A. Human catalase, its polymorphisms, regulation and changes of its activity in different diseases. Folia Biol 2014; 60 (4):153-67. [PubMed]

8. Paspalj D, Nikic P, Savic M, Djuric D, Simanic I, Zivkovic $V$, et al. Redox status in acute ischemic stroke: correlation with clinical outcome. Mol Cell Biochem 2015; 406(1-2):75-81. [CrossRef] [PubMed]

9. Milanlioglu A, Aslan M, Ozkol $H$, Çilingir V, Nuri Aydın $M$, Karadas S. Serum antioxidant enzymes activities and oxidative stress levels in patients with acute ischemic stroke: influence on neurological status and outcome. Wien Klin Wochenschr 2016; 128(5-6):169174. [CrossRef] [PubMed]

10. Žitňanová I, Šiarnik P, Kollár B, Chomova M, Pazderova $P$, Andrezalova $L$, et al. Oxidative Stress Markers and Their Dynamic Changes in Patients after Acute Ischemic Stroke. Oxid Med Cell Longev 2016; 2016: 9761697.[CrossRef] [PubMed]

11. Available from: URL: http://www.ensembl.org/Homo_sapiens/Transcript/Su mmary?db=core; $g=$ ENSG00000121691; $r=11: 344561$ 49-34456964; $t=$ ENST00000241052

12. Chistiakov A, Zotova EV, Savostanov KV, Bursa TR, Galeev IV, Strokov IA, et al. The 262T>C promoter polymorphism of the catalase gene is associated with diabetic neuropathy in type 1 diabetic Russian patients. Diabetes Metab 2006; 32:63-8.

[CrossRef] [PubMed] 
13. Quick SK, Shields PG, Nie J, Platek ME, McCann SE, Hutson $A D$, et al. Effect modification by catalase genotype suggests a role for oxidative stress in the association of hormone replacement therapy with postmenopausal breast cancer risk. Cancer Epidemiol Biomarkers Prev 2008; 17(5):1082-7. [CrossRef] [PubMed]

14. Ezzikouri $S$, El Feydi $A E$, Afifi R, Benazzouz M, Hassar $M$, Pineau $P$, et al. Polymorphisms in antioxidant defence genes and susceptibility to hepatocellular carcinoma in a Moroccan population. Free Radic Res 2010; 44(2):208-16. [CrossRef] [PubMed]

15. Khodayari S, Salehi Z, Fakhrieh Asl S, Aminian K, Mirzaei Gisomi N, Torabidalivandan S. Catalase gene C-262T polymorphism: importance in ulcerative colitis. J Gastroenterol Hepatol 2013; 28:819-22. [CrossRef] [PubMed]

16. Hebert-Schuster M, Fabre EE, Nivet-Antoine V. Catalase polymorphisms and metabolic diseases. Curr Opin Clin Nutr Metab Care 2012; 15:397-402. [CrossRef] [PubMed]

17. Forsberg $L$, Lyrenas $L$, de Faire $U$, Morgenstern R. A common functional C-T substitution polymorphism in the promoter region of the human catalase gene influences transcription factor binding, reporter gene transcription and is correlated to blood catalase levels. Free Radic Biol Med 2001; 30:500-5. [CrossRef] [PubMed]

18. Goth L. A simple method for determination of serum catalase activity and revision of reference range. Clin Chim Acta 1991; 196(2-3):143-52. [CrossRef] [PubMed]

19. Nanetti L, Raffaelli F, Vignini A, Perozzi C, Silvestrini M, Bartolini $M$, et al. Oxidative stress in ischaemic stroke. Eur J Clin Invest 2011; 41(12):1318-22. [CrossRef] [PubMed]

20. Ozkul A, Akyol A, Yenisey C, Arpaci E, Kiylioglu N, Tataroglu C. Oxidative stress in acute ischemic stroke. J Clin Neurosci 2007; 14(11):1062-6.
[CrossRef] [PubMed]

21. Sheikh N, Tavilani H, Rezaie A, Vaisi-raygani A, Salimi $\mathrm{S}$. Relationship between estradiol and antioxidant enzymes activity of ischemic stroke. J Biomed Biotechnol 2009; 1-5: 841468. [CrossRef] [PubMed]

22. Cojocaru IM, Cojocaru M, Sapira V, Ionescu A. Evaluation of oxidative stress in patients with acute ischemic stroke. Rom J Intern Med 2013; 51(2):97-106. [PubMed]

23. Kocaturk PA, Akbostanci MC, Isikay C, Ocal A, Tuncel D, Kavas GO, et al. Antioxidant status in cerebrovascular accident. Biol Trace Elem Res 2001; 80:11524. [CrossRef] [PubMed]

24. Leinonen JS, Ahonen JP, Lonnrot $K$, Jehkonen M, Dastidar $\mathrm{P}$, Molnár $\mathrm{G}$, et al. Low plasma antioxidant activity is associated with high lesion volume and neurological impairment in stroke. Stroke 2000; 31:33-9. [CrossRef] [PubMed]

25. Min JY, Lim SO, Jung G. Downregulation of catalase by reactive oxygen species via hypermethylation of CpG island II on the catalase promoter. FEBS Lett 2010; 584(11):2427-32. [CrossRef] [PubMed]

26. Lehane C, Guelzow T, Zenker S, Erxleben A, Schwer CI, Heimrich B, et al. Carbimazole is an inhibitor of protein synthesis and protects from neuronal hypoxic damage in vitro. J Pharmacol Exp Ther 2013; 347 (3): 781-93. [CrossRef] [PubMed]

27. Ahn J, Nowell S, McCann SE, Yu J, Carter L, Lang NP, et al. Associations between catalase phenotype and genotype: modification by epidemiologic factors. Cancer Epidemiol Biomarkers Prev 2006; 15(6):1217-22. [CrossRef] [PubMed]

28. Bastaki M, Huen K, Manzanillo P, Chande N, Chen C, Balmes JR, et al. Genotype-activity relationship for Mn-superoxide dismutase, glutathione peroxidase 1 and catalase in humans. Pharmacogenet Genomics 2006; 16:279-86. [CrossRef] [PubMed] 


\title{
UTICAJ CAT-262 C/T POLIMORFIZMA NA AKTIVNOST KATALAZE U PLAZMI BOLESNIKA SA ISHEMIJSKIM MOŽDANIM UDAROM
}

\author{
Jelena Bašići ${ }^{1}$, Vuk Milošević ${ }^{2}$,Milena Despotović ${ }^{1}$, Tatjana Jevtović-Stoimenov ${ }^{1}$, \\ Tatjana Cvetković ${ }^{1}$, Milica Živanović ${ }^{1}$, Miroslava Živković2,3, Dušica Pavlović ${ }^{1}$
}

\author{
${ }^{1}$ Univerzitet u Nišu, Medicinski fakultet, Katedra za biohemiju, Niš, Srbija \\ ${ }^{2}$ Klinika za neurologiju, Klinički centar Niš, Srbija \\ ${ }^{3}$ Univerzitet u Nišu, Medicinski fakultet, Niš, Srbija \\ Kontakt: Jelena Bašić \\ Medicinski fakultet Univerziteta u Nišu \\ Bulevar dr Zorana Đinđića 81, 18000 Niš, Srbija \\ E-mail: jelena.basic@medfak.ni.ac.rs
}

Iako je poznato da oksidativni stres ima važnu ulogu u etiopatogenezi akutnog ishemijskog moždanog udara (AIMU), uticaj $-262 \mathrm{C} / \mathrm{T}$ polimorfizma gena za katalazu (CAT) na njenu aktivnost u plazmi ovih bolesnika još uvek nije poznat.

Cilj rada bio je ispitivanje distribucije $C$ gena za katalazu kod bolesnika sa AIMU u odnosu na zdrave ispitanike, kao i ispitivanje uticaja ovog polimorfizma na aktivnost katalaze u plazmi bolesnika.

Istraživanje je obavljeno na 34 bolesnika sa dijagnozom AIMU i 32 zdrava ispitanika. Polimorfizam CAT-262C/T ispitivan je metodom polymerase chain reaction restriction fragment length polymorphism (PCR-RFLP). Aktivnost katalaze u plazmi određena je spektrofotometrijskom metodom po Gothu.

Iako bolesnici sa dijagnozom AIMU imaju višu frekvencu polimorfnog $-262 T$ alela ispitivanog polimorfizma od zdravih subjekata, razlika nije statistički značajna $(p=0,117)$. Kod bolesnika sa dijagnozom AIMU značajno je niža aktivnost katalaze u plazmi $(12,95 \pm 2,86$ $\mathrm{kU} / \mathrm{L})$ u odnosu na kontrolu $(25,58 \pm 13,50 \mathrm{kU} / \mathrm{L}, \mathrm{p}<0,001)$, pri čemu bolesnici koji su nosioci polimorfnog -262T alela imaju značajno nižu aktivnost enzima $(11,93 \pm 2,82 \mathrm{kU} / \mathrm{L}) \mathrm{u}$ odnosu na nosioce CC genotipa $(13,99 \pm 2,59 \mathrm{kU} / \mathrm{L}, \mathrm{p}=0,039)$ CAT-262C/T polimorfizma.

Ovo je prvo istraživanje koje ispituje CAT-262C/T polimorfizam i njegov uticaj na aktivnost katalaze u plazmi bolesnika sa AIMU. Imajući u vidu da prisustvo polimorfnog $-262 \mathrm{~T}$ alela kod bolesnika značajno smanjuje aktivnost katalaze u plazmi u poređenju sa nosiocima CC genotipa, buduća istraživanja trebalo bi usmeriti na ispitivanje potencijalnog protetektivnog efekta nosilaštva -262CC genotipa u AIMU.

Acta Medica Medianae 2018;57(4):110-116.

Ključne reči: ishemijski moždani udar, katalaza, CAT-262C/T polimorfizam 